\title{
DIGLOSIA
}

Volume 2, Nomor 2 (Agustus 2019)

p-ISSN 2615-725X (Print)

Halaman 115-126

e-ISSN 2615-8655 (Online)

\section{PEMBELAJARAN KETERAMPILAN BERBICARA DENGAN METODE FIELD TRIP PADA PESERTA DIDIK KELAS IX SMP SAMARINDA}

\author{
Sri Mulyo ${ }^{1, *}$, Mohammad Ilyas ${ }^{2}$, dan Ahmad Ridhani ${ }^{3}$ \\ ${ }^{1}$ Magister Pendidikan Bahasa dan Sastra Indonesia, FKIP, Universitas Mulawarman \\ ${ }^{2,3}$ Fakultas Keguruan dan Ilmu Pendidikan, Universitas Mulawarman \\ 1,*Pos-el korespondensi: srimulyo2016@yahoo.com \\ 2Pos-el: milyas1010@gmail.com \\ ${ }^{3}$ Pos-el: ridhaniahmad16@gmail.com
}

\begin{abstract}
The learning method, especially in speaking skill learning, is less varied, consequently the learning process tends to be unable to explore the student's competence in speaking. Therefore, the researcher sees the need to develop FT-V learning method. The objective of this study is to develop FT-V learning method for the ninth graders in Madina integrated Islamic junior high school Samarinda. This study uses Research \& Development (R\&D) method by using development proposed by Brog and Gall which includes 10 develipments steps. The data sources in this study are nine grade students in Madina integrated Islamic junior bigh school Samarinda. Data collection is done by means of sequencing, tests, observations, interviews, and documentation. The development of this learning method was declared very feasible by both validators, namely expert validator of learning method and Practitioners. Based on the results of the field tests, FT-V method was also considered to be able to increase the value of student learning outcomes through a field test process. The observation results of student's learning activities by observer I and II stated very well.
\end{abstract}

Keywords: FT-V method; speaking skill learning

\begin{abstract}
ABSTRAK
Metode pembelajaran khususnya pada pembelajaran keterampilan berbicara masih kurang variatif akibatnya proses pembelajaran yang cenderung kurang mampu mengeksplorasi kemampuan berbicara peserta didik. Untuk itu, peneliti melihat perlunya melakukan pengembangan metode pembelajaran FT-V (Field Trip and Video) dalam pembelajaran keterampilan berbicara. Tujuan penelitian ini ialah untuk mengembangan metode FT-V dalam pembelajaran berbicara. Penelitian ini menggunakan metode Research and Development (R\&D), yang dikemukakan oleh Brog and Gall yang terdiri atas sepuluh langkah pengembangan. Sumber data dalam penelitian ini ialah peserta didik kelas IX SMP Islam Terpadu Madina Samarinda. Pengumpulan data dilakukan dengan cara melakukan pengisian angket, tes, observasi, wawacaran dan dokumentasi. Pengembangan metode pembelajaran ini dinyatakan sangat layak oleh kedua validator, yakni validator ahli metode pembelajaran dan validator praktisi pembelajaran. Berdasarkan hasil uji lapangan, metode FT- $V$ ini juga dinilai dapat meningkatkan nilia hasil belajar peserta didik melalui proses uji lapangan. Hasil pengamatan kegiatan pembelajaran oleh pengamat I dan II menyatakan sangat baik.
\end{abstract}

Kata Kunci: metode FT-V; pembelajaran keterampilan berbicara 


\section{A. PENDAHULUAN}

Pembelajaran yang masih cenderung berpusat pada guru terutama pada pembelajaran berbicara (menyampaikan laporan peristiwa) menyebabkan peserta didik kurang aktif dan terlihat kurang semangat. Metode konvensional yang dimaksud misalnya pada pembelajaran kompetensi ini, guru membawakan sebuah koran/majalah yang berisi laporan sebuah peristiwa, baik peristiwa sosial maupun peristiwa alam. Kemudian, peserta didik diminta untuk memilih laporan peristiwa tertentu untuk disampaikan ulang di dalam kelas secara lisan dan peserta didik lainnya menyimak. Kegiatan pembelajaran dengan metode seperti ini kurang menuntut peserta didik untuk berpikir lebih keras dalam mengeklorasi potensinya. Untuk itu diperlukan inovasi metode pembelajaran agar tujuan pembelajaran dapat benarbenar tercapai.

Seiring semakin pesatnya perkembangan teknologi dan informasi, sebagai salah satu sekolah yang berada di daerah perkotaan sudah selayaknya pembelajarannya senantiasa didukung dengan teknologi. Media yang digunakan dalam kegiatan ini ialah media audio-visual dengan dua jenis penggunaan. Pertama media audio-visual yang digunakan oleh guru untuk menyampaikan materi dan juga memberikan contoh penyampaikan laporan peristiwa. Kedua, media yang digunakan oleh peserta didik untuk memproduksi laporan peristiwa yang nantinya dapat disaksikan bersama-sama.

Observasi proses pembelajaran dilakukan dengan melakukan pengamatan terhadap sikap belajar para peserta didik saat pembelajaran berlangsung. Informasi yang dapat digambarkan ialah adanya indikasi-indikasi peserta didik yang kurang semangat dan beberapa di antaranya tertidur saat pembelajaran. Selain ada yang tidur, fenomena peserta didik yang bicara dengan temannya atau melakukan hal-hal yang tidak ada kaitannya dengan pembelajaran juga dijumpai. Kemudian, peneliti melakukan observasi terhadap hasil belajar peserta didik berbicara (menyampaikan laporan peristiwa/hasil observasi) menunjukkan hasil yang masih rendah, yakni 76,00 dari KKM kelas 78,00. Hal ini menunjukkan bahwa keterampilan berbicara peserta didik SMP Islam Terpadu Madina khususnya kelas IX masih perlu ditingkatkan setidaknya bisa mencapai nilai rerata di atas KKM.

Dengan adanya keadaan tersebut, maka dianggap perlu melakukan penelitian pengembangan khususnya untuk mengembangkan metode pembelajaran keterampilan berbicara. Penelitian dan pengembangan metode ini dilakukan dengan tujuan untuk mengetahui desain produk pengembangan metode $F T-V$ dan keefektifannnya dalam pembelajaran keterampilan berbicara.

\section{B. KERANGKA TEORI}

\section{Metode Pembelajaran}

Sebagaimana diketahui bahwa metode adalah cara teratur yang digunakan untuk melaksanakan suatu pekerjaan agar tercapai sesuai yang dikehendaki; cara kerja yang bersistem untuk memudahkan pelaksanaan suatu kegiatan guna mencapai tujuan yang ditentukan (Muljadi et al., 2016). Metode merupakan salah satu strategi atau cara yang digunakan oleh guru dalam proses pembelajaran bagang hendak dicapai, semakin tepat metode yang digunakan oleh seorang guru maka pembelajaran akan semakin baik. Metode berasal dari kata methodos dalam bahasa Yunani yang berarti cara atau jalan. Sudjana (2005:76) berpendapat bahwa metode merupakan perencanaan secara menyeluruh untuk menyajikan materi pembelajaran bahasa secara teratur, tidak ada satu bagian yang bertentangan, dan semuanya berdasarkan pada suatu pendekatan tertentu. Pendekatan bersifat aksiomatis yaitu pendekatan yang sudah jelas kebenarannya, sedangkan metode bersifat prosedural yaitu pendekatan 
dengan menerapkan langkah-langkah. Metode bersifat prosedural maksudnya penerapan dalam pembelajaran dikerjakan melalui langkah-langkah yang teratur dan secara bertahap yang dimulai dari penyusunan perencanaan pengajaran, penyajian pengajaran, proses belajar mengajar, dan penilaian hasil belajar.

Metode field trip adalah cara mengajar yang dilaksanakan dengan mengajak peserta didik ke suatu tempat atau objek tertentu di luar kelas/sekolah untuk mempelajari atau menyelidiki sesuatu, seperti meninjau pabrik sepatu, bengkel mobil, toserba, dan sebagainya (Asmani 2010:150). Field trip bukan sekadar rekreasi semata, akan tetapi belajar atau memperdalam suatu pelajaran dengan melihat kenyataannya Roestiyah (dalam Asmani 2010:150). Metode field trip dilaksanakan dengan mengajak peserta didik belajar di luar kelas/sekolah dengan panduan guru melalui petunjuk dan tugas pelaksanaan kegiatan secara tertulis. Adanya petunjuk dan tugas yang jelas dari guru bertujuan agar kegiatan yang dilakukan di luar kelas dapat berjalan sesuai dengan tujuan dan rencana pembelajaran. Lebih lanjut, Majid (2017:215) menyatakan bahwa metode field trip mempunyai arti kunjungan ke luar kelas dalam rangka belajar. Sebagai contoh mengajak peserta didik berkunjung ke gedung pengadilan untuk mengetahui sistem peradilan dan proses pengadilan selama jam pelajaran. Jadi field trip tidak terlalu jauh dari sekolah.

Berdasarkan penjelasan di atas, dapat disimpulkan bahwa metode field trip adalah metode pembelajaran yang dilaksanakan di luar kelas dengan mengunjungi suatu tempat untuk mempelajari sesuatu. Metode field trip membantu peserta didik mendapatkan gambaran konkret tentang objek (hal) yang sedang dipelajari. Pada penelitian ini peneliti menerapkan metode field trip dalam pembelajaran keterampilan berbicara (menyampaikan laporan peristiwa) pada mata pelajaran Bahasa Indonesia.

Untuk mewujudkan pembelajaran dengan menerapkan metode field trip ada beberapa langkah yang harus dilakukan oleh guru. Menurut Sanders (2008:213), ada lima langkah untuk mewujudkan field trip yang menakjubkan (the best field trip ever), yaitu: (1) determine goals and objectives (menentukan tujuan dan sasaran utama); (2) explore all options (menjelajah semua pilihan); (3) create your itinenary (membuat rencana perjalanan); (4) check your checklist (memeriksa daftar cek); dan (5) follow-up in the classroom (tindak lanjut).

\section{Keterampilan Berbicara}

Berbicara secara umum dapat dimaksudkan sebagai sebuah keterampilan guna menyampaikan ide, gagasan seseorang kepada orang lain dengan menggunakan bahasa lisan. Menurut Tarigan (1990:15), berbicara adalah kemampuan mengucapkan bunyi-bunyi artikulasi untuk mengekspresikan, menyatakan, serta menyampaikan pikiran, gagasan, dan perasaan. Nurgiyantoro menambahkan bahwa berbicara adalah aktivitas berbahasa kedua yang dilakukan manusia dalam kehidupan bahasa setelah mendengarkan. Untuk dapat berbicara dalam suatu bahasa secara baik, pembicara harus menguasai lafal, struktur, dan kosa kata yang bersangkutan. Selain itu, diperlukan juga penguasaan masalah atau gagasan yang akan disampaikan serta kemampuan memahami bahasa lawan bicara. Sedangkan wujud dari berbicara sendiri dipandang sebagai sebuah alat berkomunikasi dengan kebutuhan penyimak penerimaan pesan yang telah disusun dalam pikiran pembicara.

Berdasarkan penjelasan di atas maka dapat disimpulkan bahwa berbicara ialah aktivitas memproduksi kata/kalimat/pesan untuk disampaikan kepada orang lain secara lisan. Istilah lain, berbicara juga dapat dinamai sebagai peristiwa tindak tutur karena melibatkan 
penutur dan lawan tutur atau komunikan dengan kominkator. Dalam bahasa lisan, kemampuan seseorang mengucapkan lambang-lambang bahasa menjadi faktor penentu keberhasilan komunikasi.

\section{Media Pembelajaran}

Media audio-visual dalam pembelajaran merupakan media yang dapat menampilkan gambar dan suara secara terpadu pada saat mengomunikasikan pesan atau informasi (Wati, 2016:44). Dalam hal ini, media video dapat dikategorikan sebagai media audio-visual. Walaupun bentuk fisiknya berbeda, media audio-visual memiliki kesamaan dengan film, yakni sama-sama mampu menampilkan gambar bergerak dan bersuara.

Media audio-visual merupakan media pembelajaran yang mengombinasikan visualisasi (tayangan) dengan audio (pendengaran suara). Arsyad (2015:146) mengungkapkan hal senada bahwa media pembalajaran yang merupakan gabungan slide (film bingkai) dengan tape audio adalah jenis sistem multimedia yang paling mudah diproduksi. Sistem multimedia ini termasuk serba guna, mudah digunakan, dan cukup efektif untuk pembelajaran kelompok atau individu (pembelajaran mandiri).

Abidin (2016:39) menuturkan bahwa pembelajaran merupakan serangkaian aktivitas terencana yang dilakukan peserta didik untuk mencapai tujuan tertentu di bawah bimbingan, arahan, dan motivasi guru. Sehingga pembelajaran tidak dapat dilakukan asal-asalan melainkan harus dilakukan secara terencana dengan baik. Proses perencanaan ini tidak hanya menyusun RPP, melainkan proses yang sistematis yang dilakukan mulai tahap penentuan kebutuhan hingga menguji keefektifan desain pembelajaran.

Lebih lanjut, Dick, Carey, dan Carey (dalam Abidin, 2016:40) menyatakan bahwa desain pembelajaran sebagai sebuah sistem dan menganggap bahwa pembelajaran adalah sebuah proses yang sistematis. Desain pembelajaran adalah sebuah upaya untuk mengingkatkan hasil pembelajaran dengan menggunakan pendekatan sistem pembelajaran. mereka juga memandang bahwa pendekatan sistem selalu mengacu pada pandangan umum sistem pengembangan pembelajaran, sebab istilah ID (intructional design) mengacu pada instructional system development (ISD), yakni tahapan analisis, desain, pengembangan, implementasi, dan evaluasi.

Sebagaimana yang disebutkan Asmani (2010) dalam penelitiannya, pengembangan metode field trip ini dirancang dengan tiga kegiatan pembelajaran, yaitu persiapan, pelaksanaan, dan penutup. Dalam penelitian ini, peneliti mendesain pembelajaran berbicara (melaporkan peristiwa) dengan metode field trip dengan media audio-visual peserta didik kelas IX SMP Islam Terpadu Madina Samarinda terdiri atas tiga kegiatan utama.

\section{Materi Pembelajaran}

Laporan peristiwa merupakan suatu keterangan mengenai suatu peristiwa atau perihal yang ditulis berdasarkan berbagai data, fakta, dan keterangan yang melingkupi peristiwa atau perihal penting lainnya yang dianggap laik untuk diketahui masyarakat. Laporan peristiwa juga dapat disebut sebagai berita atau hal yang patut diberitakan. Laporan peristiwa dapat disampaikan secara tertulis dan atau lisan.

Laporan peristiwa atau hasil observasi yang setidaknya memuat enam unsur penting yang dikenal dengan sebutan $5 \mathrm{~W}$ $+1 \mathrm{H}$. What, menanyakan jenis peristiwa atau objek yang disampaikan dalam laporan itu. Who, menanyakan siapa pelaku atau korbannya dalam peristiwa tersebut. Where, menanyakan tempat atau lokasi peristiwa. When, menanyakan kapan atau waktu peristiwa itu terjadi atau hal-hal terkait dengan objek pengamatan. Why, menanyakan alasan atau sebab terjadinya 
peristiwa atau hal-hal yang terkait. How, kata ini dapat digunakan untuk menanyakan informasi terkait proses kejadiannya atau kondisi/dampak peristiwa yang terjadi.

\section{METODE PENELITIAN}

Penelitian yang digunakan oleh peneliti pada penelitian ini ialah penelitian pengembangan (Research and Development). Borg \& Gall (Setyosari, 2010:194) mengemukakan bahwa penelitian pengembangan adalah suatu proses yang dipakai untuk mengembangkan dan memvalidasi produk pendidikan. Penelitian pengembangan mengikuti langkah-langkah secara siklus. Penelitian pengembangan itu sendiri dilakukan berdasarkan suatu model pengembangan berbasis industri, yang temuan-temuannya didesain untuk merancang produk dan prosedur yang kemudian secara sistematis dilakukan uji lapangan, dievaluasi dan disempurnakan untuk memenuhi kriteria keefektifan, kualitas dan standar tertentu (Borg \& Gall dalam Sugiyono, 2017:34).

Lebih jauh Sugiyono (2009:297) mengemukakan bahwa Research and Development adalah metode penelitian yang digunakan untuk menghasilkan produk tertentu, dan menguji keefektifan metode tersebut. Sementara itu, di bidang pendidikan Borg \& Gall (1985) menyatakan bahwa penelitian pengembangan merupakan metode penelitian yang digunakan untuk mengembangkan, memvalidasi produk yang digunakan dalam pendidikan dan pembelajaran (Sugiyono, 2009:4).

Berdasarkan penjelasan di atas maka dapat disimpulkan bahwa penelitian pengembangan ialah jenis metode penelitian yang berupaya untuk menemukan, mengembangkan dan atau menghasilkan produk tertentu serta memvalidasi hasil temuan sehingga dapat dipercaya tingkat kebenarannya.

Penelitian pengembangan ini memiliki tujuan untuk melakukan perubahan-perubahan dan melihat perubahan-perubahan yang terjadi dalam kurun waktu tertentu. Sugiyono (2018:167) dalam hal ini juga mengemukakan bahwa penelitian pengembangan ini memiliki tujuan untuk mengembangkan, menemukan, dan memvalidasi suatu produk. Menemukan adalah melakukan penelitian awal yang bertujuan untuk mendapatkan pengetahuan baru tentang konsep dasar. Mengembangkan yaitu bertujuan mengembangkan pengetahuan yang sudah dimiliki atau diperoleh sejak awal. Memvalidasi berarti upaya menguji keefektifan produk-produk yang merupakan hasil pengembangan.

Subjek penelitian pengembangan ini adalah peserta didik kelas IX SMP Islam Tepadu Madina Samarinda. Pelaksanaan pengembangan metode pembelajaran direncanakan untuk dapat dilaksanakan penelitian pengembangan, yaitu pada semester genap tahun pelajaran 2018/2019. Pemilihan SMP Islam Terpadu Madina sebagai subjek penelitian atas beberapa pertimbangan: kondisi peserta didik yang beragam baik secara kemampuan akademik, jenis kelamin dan latar belakang keluarga serta daerah asal peserta didik. kedua kemudahan akses perizinan kepada pihak sekolah, ketiga kemudahan akses terhadap peserta didik yakni kapan saja peneliti memerlukan peran peserta didik mereka selalu berada di sekolah karena sekolah tersebut menggunakan sistem boarding school.

Penelitian pengembangan ini menerapkan sepuluh langkah pengembangan sebagaimana yang dikemukakan Borg \& Gall (dalam Sugiyono 2018:298) menjelaskan setidaknya ada sepuluh langkah yang dapat ditempuh dalam melaksanakan penelitian pengembangan. Langkah-langkah tersebut adalah sebagai berikut.

(1) Penelitian dan pengumpulan informasi (reserch and information collecting), yaitu pengumpulan data 
awal di lapangan yang dijabarkan/dipaparkan dalam bentuk studi literatur, observasi lapangan berkenaan dengan pelajaran bahasa indonesia, ketersediaan alat bantu pembelajaran, serta kondisi peserta didik dan juga guru;

(2) Perencanaan (planning), yakni menyusun rencana penelitian yang meliputi kemampuan-kemampuan yang diperlukan dalam pelaksanaan penelitian, perumusan tujuan yang akan dicapai dalam penelitian, desain atau langkah-langkah penelitian, dan melakukan evaluasi;

(3) Develop prelimenary form and product, yaitu mengembangkan bentuk model awal, mengumpulkan dan menyusun materi ajar, merancang bentuk awal produk yang ingin diciptakan.

(4) Uji lapangan awal (prelimenay field testing), yaitu melakukan uji coba strategi secara individual untuk mendapatkan informasi tentang kelemahan dan kekurangan produk yang dikembangkan.

(5) Revisi utama produk (main product revision), yaitu memperbaiki hasil uji coba atau perbaikan model awal;

(6) Uji coba lapangan utama (main field testing), yaitu uji coba produk dengan memperluas area dan memperbanyak subjek penelitian;

(7) Revisi produk (development revision product), ialah menyempurnakan produk hasil uji lapangan, dilakukan berdasarkan hasil uji coba utama atau perbaikan hasil uji coba produk lebih luas;

(8) Uji lapangan operasional (operational field testing), yakni langkah uji validasi terhadap produk yang dihasilkan untuk membuat draf terakhir produk sebelum disebarluaskan untuk diimplementasikan;

(9) Revisi produk akhir (final product revision), yaitu penyempurnaan akhir produk berdasarkan uji pelaksanaan lapangan dengan memerhatikan hasil wawancara atau observasi langsung saat pelaksaaan uji coba;

(10) Diseminasi dan implementasi produk (dissemination and implementation), yaitu menyebarluaskan dan mengimplementasikan produk yang dihasilkan dari hasil penelitian pengembangan.

Pengumpulan data merupakan inti dari setiap kegiatan penelitian. Sebagaimana yang dikemukakan Richey \& Klein (dalam Sugiyono, 2017:200) bahwa "the data reseacrhers collected depend on the nature of their research question and hypotheses." Data yang dikumpulkan peneliti tergantung pada rumusan masalah dan hipotesis. Lebih lanjut Sugiyono (2011:225) menjelaskan bahwa dalam pengumpulan data kualitatif dilakukan secara alamiah. Bila ditinjau dari teknik pengumpulan data maka teknik dapat dilakukan dengan observasi, wawancara, kuesioner, dan dokumentasi (Sugiyono, 2011:225).

Dalam penelitian pengembangan metode FT-V pada pembelajaran keterampilan berbicara (menyampaikan laporan peristiwa atau hasil observasi) ini ada tiga teknik pengumpulan data yang peneliti gunakan. Tiga teknik yang digunakan itu meliputi observasi, wawancara, dan dokumentasi proses dan hasil pembelajaran. Observasi untuk mengetahui kondisi alamiah yang terdapat pada peserta didik dan juga guru selama proses pembelajaran. Wawancara untuk menggali informasi lebih mendalam mengenai minat belajar peserta didik dalam pembelajaran dan kualitas produk. Dokumentasi sebagai bagian penting sebab dalam penelitian ini dokumentasi dalam bentuk video merupakan produk laporan yang dibuat peserta didik dalam proses pembelajaran menyampaikan laporan peristiwa.

Teknik analisis data bertujuan untuk mengolah data yang dihimpun dari hasil wawancara maupun observasi (Sari, 
2017:65). Teknik dalam melakukan analisis data pada penelitian pengembangan ini yakni menggunakan teknik analisis level 4. Analisis data level 4 ialah analisis data untuk meneliti dan menggunakan yang bertujuan mendapatkan produk baru (Sugiyono, 2017:250). Teknik analisis pada penelitian pengembangan menggunakan dua jenis anilisis, yaitu analisis kuantitatif dan analisis kualitatif.

\section{HASIL DAN PEMBAHASAN}

\section{Pengembangan Desain Produk}

Secara operasional, kegiatan yang dilakukan pada tahap desain produk metode pembelajaran dengan metode FT$V$ meliputi: (a) melakukan kajian kurikulum dan mengkaji teori-teori yang mendukung; (b) menentukan kompetensi dasar yang ingin diajarkan; (c) merumuskan indikator pencapaian kompetensi atau tujuan pembelajaran yang ingin dicapai; (d) menyusun RPP; (e) mengumpulkan bahan/materi ajar; (f) menentukan metode pembelajaran yang akan digunakan; (g) menyusun langkahlangkah pembelajaran; (h) merumuskan jenis dan teknik penilaian hasil pembelajaran atau evaluasi.

Hasil penelitian pengembangan ini berupa metode pembelajaran FT-V dalam pembelajaran keterampilan berbicara pada kompetensi dasar menyampaikan laporan peristiwa atau hasil observasi setidaknya ada tiga langkah utama yang dilakukan dalam proses pembelajaran, yakni kegiatan pendahuluan, kegiatan pelaksanaan pembelajaran dan kegiatan akhir pembelajaran. berikut ini langkah-langkah pembelajaran menyampaikan laporan atau hasil observasi secara lisan dengan metode FT-V.

\section{a. Tahap Persiapan}

Tahap persiapan dalam kegiatan pembelajaran keterampilan berbicara dengan metode FT- $V$ dibedakan menjadi dua bagian yaitu pertama persiapan pembelajaran dan persiapan teknis. Pertama persiapan pembelajaran meliputi persiapan yang berkaitan secara langsung dengan proses pembelajaran yang akan dilakukan. Kedua, persiapan teknis ialah kegiatan persiapan yang berkaitan dengan hal-hal teknis dan tidak berkaitan langsung. Berikut ini tahapan persiapan dalam pembelajaran FT- $V$.

\section{(1) Persiapan Pembelajaran}

Tahap persiapan pembelajaran dalam pembelajaran keterampilan berbicara menggunakan metode FT- $V$ terdiri atas beberapa kegiatan berikut ini.

(a) Menentukan kompetensi dasar yang akan diajarkan. Kompetensi Dasar (KD) yang akan diajarkan atau dicapai dalam pembelajaran harus ditetapkan sejak awal agar dapat disesuaikan dengan metode pembelajaran yang akan digunakan.

(b) Menetapkan tujuan pembelajaran dengan jelas. Tujuan pembelajaran dengan metode field trip dalam pembelajaran keterampilan berbicara ialah semakin meningkatnya keterampilan berbicara siswa sesuai kebutuhan dan perubahan sikap belajar menjadi lebih baik.

(c) Menyusun Rencana Pelaksanaan Pembelajaran (RPP). RPP disusun setelah guru menetapkan $\mathrm{KD}$ dan tujuan pembelajaran untuk menjadi panduan pelaksanaan pembelajaran.

(d) Memilih materi/bahan ajar yang akan diajarkan dalam kegiatan field trip. Materi atau bahan ajar yang akan digunakan ialah menyampaikan laporan berbagai peristiwa secara lisan menggunakan menggunakan bahasa yang lugas.

(e) Menyusun Lembar Kerja Peserta Didik (LKPD). LKPD yang disusun dapat berupa panduan kegiatan pembelajaran untuk peserta didik dan atau panduan penyusun laporan hasil observasi berupa reportase atau lainnya. 
(f) Menyiapkan media pembelajaran. media pembelajaran yang pilih harus disesuaikan dengan kompetensi dasar yang akan diajarkan.

\section{(2) Persiapan Teknis}

Kegiatan persiapan dalam pembelajaran keterampilan berbicara dengan metode FT- $V$ terdiri atas beberapa kegiatan berikut ini.

(a) Menetapkan lokasi/objek yang akan dikunjungi. Lokasi yang akan dikunjungi dalam kegiatan field trip dapat berupa lokasi bencana, lokasi wisata, lokasi tambang batu bara dan tempat-tempat lain yang menarik untuk diobservasi. Dalam tahap penentuan lokasi ini juga sekaligus menghubungi pengelola atau mengajukan izin kunjungan bila lokasi yang dipilih merupakan ada pengelolanya.

(b) Mengatur jadwal atau waktu kegiatan pembelajaran. Jadwal kegiatan pembelajaran mengikuti jadwal yang ditetapkan sekolah.

(c) Menentukan tata tertib selama kegiatan pembelajaran. Tata tertib pembelajaran atau selama kegiatan field trip dapat ditentukan oleh guru atau dengan cara membangun kesepakatan dengan peserta didik.

\section{b. Tahap Pelaksanaan}

Tahap pelaksanaan ada beberapa kegiatan yang dilakukan oleh guru dan peserta didik agar tujuan pembelajaran yang telah ditetapkan tercapai, guru melakukan beberapa hal antara lain.

(a) Guru menyampaikan mengenai pokok materi materi pembelajaran dan tujuan yang ingin dicapai berdasarkan kompetensi dasar yang ditetapkan.

(b) Peserta didik mengikuti pembelajaran terkait materi menyampaikan laporan peristiwa/hasil observasi.

(c) Peserta didik mendapatkan arahan/penjelasan tentang tata tertib kegiatan selama pembelajaran dengan FT-V.

(d) Peserta didik berkelompok dengan anggota 5-6 orang. Pengelompokan diatur sebelum kegiatan field trip agar pemanfaatan waktu lebih efektif.

(e) Peserta didik melakukan fiel trip atau kunjungan ke tempat tertentu yang telah disepakati.

(f) Guru memberikan tugas peserta didik melakukan observasi lapangan untuk menemukan objek yang cocok untuk diamati dengan penetapan objek berdasarkan kelompok.

(g) Peserta didik mencatat informasi penting sekaligus pengumpulan data yang menjadi objek pengamatan sebagai kerangka laporan peristiwa/hasil observasi kegiatan ini dilakukan berdasarkan jenis objek yang diamati oleh peserta didik.

(h) Peserta didik berdiskusi dengan teman sekelompok untuk menyusun laporan atas peristiwa/objek yang diamati atau ditemui.

(i) Guru memberi bimbingan/arahan/petunjuk bagi peserta didik yang memerlukan penjelasan baik dalam observasi maupun dalam penyusunan laporan.

(j) Setiap peserta didik mempelajari dan memahami laporan yang telah disusun secara berkelompok serta berlatih menyampaikan laporan secara lisan.

(k) Peserta didik bergantian dalam satu kelompok untuk menyampaikan laporan peristiwa di depan media audio-visual (kamera) untuk direkam gambar dan suaranya.

\section{c. Tahap Akhir}

Setelah kegiatan persiapan dan pelaksanaan diselesaikan maka tahap terakhir ialah tahap penutup kegiatan. Agar proses pembelajaran dengan field trip ini memberikan dampak yang posistif, maka peneliti merumuskan beberapa kegiatan yang dapat dilakukan berikut ini. 
(a) Peserta didik menyaksikan sebagian video hasil rekaman reportase yang telah dibuat untuk melakukan refleksi pembelajaran.

(b) Peserta didik dan guru tanya jawab mengenai peristiwa yang sudah dijumpai kegiatan field trip. Tanya jawab digunakan untuk melakukan refleksi proses pembelajaran.

(c) Peserta didik menyampaikan kesankesan setelah mengikuti kegiatan pembelajaran, baik terkait field trip-nya maupun penggunaan media (video) terkait laporan peristiwa, dalam hal ini kesan selama mengikuti pembelajaran dengan metode FT-V.

(d) Peserta didik dan guru merencanakan tindak lanjut hasil pembelajaran yang telah dilakukan sebagai kegiatan pengayaan. Tindak lanjut pembelajaran dapat berupa pembuatan reportase secara individu dan dilakukan perekaman masingmasing.

(e) Guru memberikan penguatan dan menyimpulkan hasil pembelajaran yang telah dilakukan.

(f) Penilaian keterampilan berbicara dilakukan dengan mengamati video hasil reportase yang telah dibuat oleh peserta didik. Penilaian dilakukan oleh guru mata pelajaran.

(g) Guru dan siswa mengakhiri proses pembelajaran dengan doa setelah belajar.

\section{Penilaian Validator}

Penilaian desain produk dilakukan untuk mengetahui tingkat validitas produk yang dikembangkan berupa metode pembelajaran FT-V dalam pembelajaran keterampilan berbicara pada KD menyampaikan laporan peristiwa/hasil observasi. Penilaian desain produk dilakukan oleh dua orang validator, yakni validator ahli dan validator praktisi pembelajaran. Validasi ahli dilakukan oleh Dr. Sudarman, S.Pd.,M.Pd sebagai dosen di Universitas Mulawarman dan validator praktisi dilakukan oleh M. Agus Kastiyawan, M.Pd, selaku guru mata pelajaran bahasa Indonesia.

Penilaian desain produk oleh validator dilakukan masing-masing sebanyak dua tahap. Penilaian tahap I dilakukan oleh validator dengan memberikan beberapa masukan untuk dilakukan penyempurnaan. Setelah penelitia melakukan penyempurnaan maka dilakukan penilaian tahap II, baik oleh validator ahli maupun validator praktisi. Data hasil pengisian angket oleh validasi ahli metode pembelajaran menunjukkan bahwa persentase produk berupa langkah-langkah pembelajaran memperoleh nilai akhir validitas ialah 87,5. Mengacu pada nilai uji validitas tersebut, produk dapat dikatakan bahwa metode field trip sangat layak untuk digunakan dalam pembelajaran tanpa revisi. Berikutnya, data hasil validasi praktisi pembelajaran menunjukkan bahwa produk pengembangan metode field trip yang tersebut dikategorikan sangat layak untuk digunakan dengan nilai akhir 90,00. Sehingga rekomendasi akhir validator praktisi pembelajaran menyatakan bahwa metode field trip dalam pembelajaran keterampilan berbicara (menyampaikan laporan peristiwa atau laporan hasil observasi) sangat layak digunakan dalam pembelajaran. tanpa direvisi.

\section{Hasil Uji Coba Produk}

Hasil Uji coba produk merupakan kegiatan untuk mengetahui apakah produk pengembangan berupa metode FT-V efektif digunakan dalam pembelajaran keterampilan berbicara. Selain untuk melihat efektivitas pembelajaran pada uji coba produk juga bertujuan untuk menguji apakah metode ini dapat meningkatkan keterampilan berbicara peserta didik. Uji coba produk dilakukan dengan dua tahap. Pertama uji coba kelompok kecil dan kedua uji coba kelompok besar. Dalam setiap uji coba dilakukan dengan dua kali tes keterampilan berbicara yakni pretes 
untuk mengetahui kondisi awa peserta didik sebelum mengikuti pembelajaran dengan metode FT-V dan postes dilakukan untuk mengetahui kemampuan berbicara peserta didik setelah mengikuti pembelajaran dengan metode FT-V.

Pelaksanaan pretes dilakukan dengan pembelajaran keterampilan berbicara menggunakan metode konvensional atau metode pembelajaran pada umumnya yakni dengan ceramah dan penugasan. Untuk melakukan tes keterampilan berbicara pada pembelajaran pretes ini, guru menyampaikan sekilas materi pembelajaran, kemudian peserta didik ditugas untuk mencari infomasi di koran/kejadian yang pernah dialami/dijumpai untuk dilakukan pelaporan di depan kelas. Sedangkan postes dilakukan setelah peserta didik mengikuti pembelajaran keterampilan berbicara menggunakan metode FT-V. Postes ini dilakukan dengan kegiatan guru menyampaikan materi kemudian peserta didik diajak mengunjungi lokasi peternakan kadang sapi, perkebunan papaya dan juga area tambang batu bara. Kegiatan berikutnya, peserta didik mengumpulan data dan informasi untuk ditulis menjadi sebuah laporan peristiwa yang utuh. Setelah laporan selesai disusun maka peserta didik menyampaikan laporan tersebut secara lisan di depan kamera perekam. Penilaian keterampilan berbicara dilakukan guru dengan cara mengamati hasil rekaman reportase peserta didik.

Hasil pretes pada uji kelompok kecil dengan jumlah peserta didik sepuluh orang memperoleh rerata nilai 74,00. Kemudian setelah mengikuti proses pembelajaran keterampilan berbicara pada kompetensi menyampaikan laporan peristiwa/hasil observasi dengan menggunakan metode FT-V, rerata nilai meningkat menjadi 85,70. Selanjutnya, uji kelompok besar dengan jumlah peserta didik sebanyak 30 orang. Pada pretes uji kelompok besar mendapat rerata nilai 73,37 dan setelah mengikuti proses pembelajaran keterampilan berbicara pada kompetensi menyampaikan laporan peristiwa/hasil observasi dengan menggunakan metode FT- $V$ hasil postes menunjukkan adanya peningkatan yakni menjadi 85,56.

\section{Observasi Pembelajaran}

Hasil observasi pembelajaran, pengamat memberikan penilaian dengan cara mengisi rubrik isian Alat Penilaian Kinerja Guru (APKG) I dan APKG II. APKG I merupakan penilaian perencanaan pembelajaran yang secara fisik dapat mengamati dokumen RPP dan APKG II merupakan penilaian proses pelaksanaan pembelajaran di kelas dan atau di luar kelas. Berdasarkan hasil isian APKG I dan APKG II oleh pengamat I dan memberikan nilai dengan rerata 97,1 dan 97,2 Sedangkan pengamat II memberikan nilai 92,01 untuk APKG I dan 95,00 untuk APKG II dengan interpretasi kriteria sangat baik (SB). Selain melaui isian APKG yang dilakukan oleh dua orang pengamat, uji efektivitas juga dengan pengisian angket respon peserta didik dilakukakan secara langsung yang mengikuti uji produk kelompok besar dan setelah mengikuti proses pembelajaran dengan metode FT- $V$. Berdasarkan isian angket respon peserta didik diperoleh nilai 84,00 dan dapat dikategorikan sangat baik (SB).

Selanjutnya, peneliti juga melakukan pengumpulan data dengan wawancara. Wawancara dilakukan kepada guru sebagai pengguna, validator praktisi, dan peserta didik sebagai pihak yang merasakan dampak secara langsung dari penerapan metoe pembelajaran ini. Hasil wawancara dari ketiga pihak informan tersebut menyatakan bahwa metode pembelajaran FT-V ini sangat baik untuk digunakan dalam pembelajaran keterampilan berbicara, khususnya pada kompetensi menyampaikan laporan peristiwa/hasil observasi secara lisan. 


\section{Kelebihan dan kekurangan}

Metode FT-V merupakan hasil pengembangan dari metode field trip dengan penggunaan media audio visual sebagai alat perekam (pembuatan video) hasil pembelajaran. Beberapa kelebihan metode ini ialah: (a) memberikan suasana baru dalam pembelajaran sebagai proses pembelajaran di lakukan di luar kelas; (b) peserta didik dapat melihat langsung objek atau peristiwa yang sedang dijadikan sumber belajar; (c) guru tidak telalu banyak menjelaskan atau memberikan gambaran karena peserta didik melihat objek/sumber belajarnya, 4) peserta didik dapat sekaligus melakukan wisata; (e) peserta didik merasa lebih percaya diri dalam menyampaikan laporan secara lisan; (f) peserta didik sekaligus dapat berlatih mengoperasikan media atau alat perekam; dan (g) peserta didik mendapat pengamalan menjadi seorang reporter walaupun dalam tahap pembelajaran.

Di samping kelebihan tersebut, metode ini juga tentu masih terdapat kelemahan-kelemahan dalam penggunaannya, seperti: (a) pembelajaran dengan metode FT-V memerlukan waktu dan biaya yang lebih banyak jika lokasinya jauh dari sekolah; (b) pembelajaran dengan metode FT-V memerlukan koordinasi dengan banyak pihak, (c) guru perlu mengelola pembelajaran lebih ekstra dalam mengondisikan peserta didik.

\section{E. PENUTUP}

Metode FT-V merupakan perpaduan metode field trip dengan penggunaan media audio-visual sebagai alat perekam reportase laporan peristiwa atau hasil observasi. Metode pembelajaran FT-V ini dikembangkan dalam pembelajaran keterampilan berbicara. Setelah melalui sepuluh langkah pengembangan sebagaimana yang dikemukakan oleh Borg \& Gall dalam penelitian dan pengembangan ini, metode FT-V ini dinyatakan dapat digunakan dalam proses pembelajaran keterampilan berbicara.
Selain itu, metode FT-V terbukti efektif untuk meningkatkan keterampilan berbicara peserta didik, meningkatkan motvasi belajar peserta didik dan mendapat respon positif dari guru sebagai pengguna dan peserta didik sebagai penerima pembelajaran. Berdasarkan penelitian yang telah dilakukan tersebut, maka peneliti menyarankan agar: (1) pembelajaran bahasa Indonesia khususnya pada kompetensi dasar menyampaikan laporan peristiwa atau hasil observasi menggunakan metode field trip; (2) Untuk menumbuhkan sikap empati pada hal-hal tertentu, peserta didik perlu dibawa ke lokasi kejadian; (3) para guru dapat menggunakan metode ini dengan tetap menambah referensi-referensi pendukung yang dapat menguatkan penggunaan metode ini dalam pembelajaran; dan (4) Agar pembelajaran tetap efektif kegiatan filed trip dapat dilakukan di lingkungan sekitar sekolah.

\section{DAFTAR PUSTAKA}

Arsyad, A. (2013). Media Pembelajaran. Jakarta: Rajawali Pers.

Tim Pengembang KBBI V. (2016). Kamus Besar Bahasa Indonesia V Daring.

Majid, A. (2017). Strategi Pembelajaran. Bandung: PT Remaja Rosdakarya.

Rahmayanti, I., Nawawi, \& Quro, U. (2017). Keterampilan Berbicara sebagai Keterampilan Berbahasa. Jakarta: Uhamka Press.

Ranem. (2018). Pengembangan Bahan Ajar Materi Debat dengan Metode Role Playing pada Siswa Kelas X Sekolah Menengah Atas. Diglosia: Jurnal Kajian Bahasa, Sastra, dan Pengajarannya, 1(2), 65-74. Diperoleh dari

http://diglosiaunmul.com/index.ph $\mathrm{p} /$ diglosia/article/view/10

Sari, I. N. (2017). Pengembengan Strategi Pembelajaran Tandur Menggunakan Media E-Learning dalam 
Mengonversi Teks Cerita Pendek Menjadi Teks Drama Siswa Kelas XI SMAN 10 Samariinda. Tesis. Universitas Mulawarman.

Setyosari, P. (2010). Metodologi Penelitian Pendidikan dan Pengembangan. Jakarta: Kencana.
Sugiyono. (2017). Metode Penelitian dan Pengembangan (Research and Development). Bandung: Alfabeta.

Sugiyono. (2018). Metode Penelitian Kuantitatif, Kualitatif, dan R\&D. Bandung: Alfabeta. 
